\title{
FORMATION OF PROFESSIONAL SELF-ASSESSMENT OF BORDER GUARD OFFICERS-INTENDING MANAGERS
}

\section{Valentyn Demskyi}

\section{INTRODUCTION}

The main purpose of any mental phenomenon investigation is the use of the obtained knowledge in practice. Therefore, along with the theoretical consideration of reflexive processes, it is important to analyze certain properties in the practical activities of a border guard officer. The choice of management activities aimed at the analysis of the mechanisms of reflexive regulation is not accidental. Researchers have repeatedly provided a rationale for the importance of exploring reflective processes in management-related activities. Reflection is seen as a process of awareness of activity in works of philosophy and psychology, it is defined as a common component of its various types, including in the field of management. It is in this area that reflection is most important for border guard officers, because qualification of an officer presupposes managerial and organizational activities in the process of units' management, as well as the bodies of the State Border Guard Service of Ukraine and its other socio-economic systems.

Specifics of management of socio-economic systems, according to V. Polyakov ${ }^{1}$, presupposes the following basic aspects of self-esteem:

- identifying features of the awareness process of one's individual activity in making and implementing managerial decisions;

- awareness of the cooperative activities of participants in collective decision-making procedures to coordinate it;

- formation of the subject of management in the process of education.

The purpose of the article is to analyze the scientific papers presenting results of research on the concept of "self-esteem of a border guard officer" in the system of his professional activity and to create a program and model of its formation.

${ }^{1}$ Morozov, I. V., Zalozh, V. V., Shyrobokov, S. M. (2003). Naukovi osnovy upravlinnia, Chastyna I. [Scientific Foundations of Management, Part I]. Khmelnytskyi.: Vydavnytstvo Natsionalnoi akademii DPSU, 150 p. [in Ukrainian]. 


\section{Professional self-assessment of border guard officers and managing activity}

Transition from an extensive type of management to an intense one is impossible in modern society without increasing the value of reflective processes. It should be noted that the extensive type of management has given rise to a simplified view of the potential for influencing the entity through a combination of external incentives, in particular when the means and methods of management are given from the outside sources. An intensive type of management implies an awareness of the subject of management of its role, resulting in the synthesis of new principles and mechanisms of management.

In order to determine the role of self-assessment in the management activities of border guard officers and to identify the mechanisms of functioning of this characteristic property in practical activities, it is necessary to reveal the content of management activities.

It is noteworthy that management is a culture, a system of values, as well as a means for society development. Functioning of a developed society, solving important tasks is impossible without organizational and managerial institutions. Management is characteristic of any social phenomenon that is associated with joint activities to achieve common goals. Nowadays, with the development and complexity of society, it is easier to set up an enterprise than to manage it effectively. This pattern indicates the increasing role of management.

Managing an organization includes the performance of administrative and managerial functions ${ }^{2}$, aimed at the recruitment and placement of personnel, their management, as well as educating people initiative and independence, control of their work, the use of economic ways to influence the activities of the team. Management in a broad sense is a system of measures aimed at defining the goals of a particular production line, as well as the development and

${ }^{2}$ Potapchuk, Y. M. (2004). Teoriia ta praktyka zberezhennia psykhichnoho zdorovia viiskovosluzhbovtsiv: Monohrafiia [Theory and practice of maintaining the mental health of servicemen: A monograph]. Khmelnytskyi: Vydavnytstvo Natsionalnoi akademii DPSU, 323 p. [in Ukrainian]. 
implementation of actions aimed at organizing a team to achieve these goals, for systematic coherence of work, objects of work, means and all participants of the production organization, ensuring normal working conditions and improving the cultural and technical level of personnel and their socio-cultural service ${ }^{3}$. A rather broad definition of management is given to demonstrate its multidimensionality. It should be noted that management requires more complex regulation, involvement of a whole complex of processes and properties. It mainly refers to integral psychic processes, such as reflexivity. Due to their complexity and indirectness to other mental manifestations, a systematic, multidimensional approach to consideration of management activity and the importance of the reflexive processes of its regulation can be used.

To confirm the validity of the choice of research topic, to identify the value of reflective processes, according to V.G. Polyakov, considering management activities in three aspects: 1) the functions performed by the head, i.e. the content of the activity; 2) determining the professionally important qualities of a manager; 3) through characterization of principles and methods of activity training.

Such processes ${ }^{4}$ as planning (determining the ways, means and pace of achievement of intermediate and final goals), control (determining the degree of achievement of the ultimate goal or deviation from it), correction (identifying and using new or additional ways and means of achieving the final goals) are considered the main functions of management process. The object of management is the organization, that is, the system. Its components are people who hold professional positions in the organizational structure and determine the functional relationships between its components.

Management is aimed at optimizing people's professional activity through economic, administrative, psychological and pedagogical

${ }^{3}$ Morozov, I. V., Zalozh, V. V., Shyrobokov, S. M. (2003). Naukovi osnovy upravlinnia, Chastyna I. [Scientific Foundations of Management, Part I]. Khmelnytskyi.: Vydavnytstvo Natsionalnoi akademii DPSU, 150 p. [in Ukrainian].

4 Potapchuk, Y. M. (2004). Teoriia ta praktyka zberezhennia psykhichnoho zdorovia viiskovosluzhbovtsiv: Monohrafiia [Theory and practice of maintaining the mental health of servicemen: A monograph]. Khmelnytskyi: Vydavnytstvo Natsionalnoi akademii DPSU, 323 p. [in Ukrainian]. 
influences, taking into account the needs, values, and attitudes of an individual or a group. In technological terms, the basis of management processes is the acceptance and processing of information, decisionmaking in times of scarcity of time and information ${ }^{5}$.

If you consider the activities of management from the point of view of the manager, the following stages can be distinguished: diagnostics and prediction of the state of the managed system; forming a program of activities of subordinates aimed at changing the state of the object in a given direction; organization and execution of decisions. It should be noted that:

1) Programming involves predicting progress, performance, modeling and communicating the program to the object of management. In essence, the planning function covers three areas, namely the state of affairs (assessment of opportunities, taking into account external and internal factors), the goals that should be achieved, and the means required for their implementation. It is important to point to the fact that the reflexive mechanisms of planning management activities are not a single action, but an ongoing process. What really works is not the kind of management that makes decisions to solve certain problems, but the one that anticipates possible solutions and such planning of work in the organization to eliminate the need for problems solution. The skills of such advanced management, of course, require a high level of development of self-esteem abilities.

2) The function of the organization is to create a specific structure to perform the planned activities. Selection of people, delegation of tasks, powers and responsibilities for success are the main tasks of a manager in the organization of work. It also requires the ability to understand the situation in detail, the ability to freely mentally operate different parameters of the situation, to correlate its components and factors, to predict the course of future activity. Each manager should not only organize the work of his unit, but also rationally allocate his/ her own time. As it is revealed, the manager works much more effectively if he makes the program consciously, that is, if he has a tendency to self-assessment.

${ }^{5}$ Smolskij, S. M., Filippov, L. I. (2005). Tri shaga k professii: nauka, disertaciya, pedagogika [Three steps to the profession: science, dissertation, pedagogy]. Odessa: «Neptun-Tehnologiya», 125 p. [in Russian]. 
3) the function of motivation of employees provides that performers were interested in performance of work according to the rights and duties delegated to them. The motivation is paid more attention with the development of society. Nowadays, humanity considers not only physical and material (for example, such as monetary compensation) methods of increasing interest in work, but understands motivation as a process of creating an internal motivation for activity through taking into account the many needs of the employee. In this regard, the manager should study his subordinates, which requires skills of perception of the human condition, personal characteristics, motivational orientation, interests, interpretation of behavior in different situations. For an adequate understanding of the other person, the manager needs both the diagnostic skills, and reflective abilities, which are a property of the personality. It is known that a person does most willingly what he decides to do on his own. The manager has to set a task in such a way that the subordinate will consider the goal as his own and acts with initiative and creativity. The professionally important quality of the manager is the ability to accept the point of view of another person. When choosing measures to influence the misconduct and violations of subordinates, an experienced manager should always try to understand why the subordinate acted in this way, only then will he make the right decision.

It should be noted that the success of any team depends on the authority of the manager. The main feature of any authoritative manager is the ability to control the actions of others through the influence of his own personality, and this is associated with selfassessment, as well as with the awareness of capabilities and competence, understanding others expectancies, the ability of devotedness.

4) Control as a feedback function is closely related to planning. There are three aspects of management control:

- setting standards, that is, pinpointing the goals to be achieved by a specific deadline;

- identification of achievements and comparison with expected results;

- necessary actions for correction of the revealed deviations.

The imaginary actions on control, correction, and anticipation of results taken out on accurately realized analyzed levels increase 
efficiency of administrative activity, and as a result, are formed on the basis of self-assessment.

So, each of the functions of management is associated with the definition, processing, exchange of information and decision-making. The border guard officer needs to analyze many options for potential actions to find the most optimal one in a given situation. As a rule, you need to model the activity, having several alternative solutions. When making a decision, the border guard officer must choose what and how to plan, what means and ways to carry out activities, how to motivate subordinates and how to control the correction. All these actions are impossible without reflexive abilities. Given the importance of management functions, it can be argued that reflexivity, as a factor of their successful implementation, can affect both the procedural aspect of the activity and the final result.

An interesting description of the management activities of Herman A. Schreder ${ }^{6}$. The scientist analyzes what practical actions need to be applied in solving management problems. The first place, in his opinion, is the need for a clear recognition of the situation, the definition of deviations when comparing the planned and actual state of the managed system. This task is not easy, some managers can find such problems where they do not exist, or vice versa, managers cannot notice important features of the problem. Having noticed deviations, the manager should try to find the possible reasons of a deviation, and analyse the errors. The most important prerequisite for determining the causes of deviation is to find as many of them as possible. The manager who finds 15 causes of error when solving a problem is more suitable for management activities than one who names only two reasons. The ability to find more possible causes of deviation not only increases the probability of correct solution of the problem but also creates a prerequisite for more flexible solutions to problems that may arise in the future. However, only the rich imagination is not enough when looking for possible errors. It is necessary for manager to be able to conduct a detailed analysis of versions to find the truth. The manager must then identify possible measures and ways of behaving in

${ }^{6}$ Manhutov, Y. S., Umanskyi, L. Y. (1975). Orhanizator i orhanizatorskaia deiatelnost [Organizer and organizing activity]. Lviv, 310 p. [in Russian]. 
the situation. To do this, he needs to make an analysis of the measures provided for by the instructions and recommendations, assess his own experience, consider the measures already taken. Then he chooses ways to behave. However, most often under different circumstances, there are no necessary instructions for behavior. The choice of new methods makes you think about what the consequences may be after the application of certain measures. This means that the manager must consider the various consequences and know the advantages and disadvantages of certain activities. The last action-the test of success-is needed to find out whether the new West has contributed to reducing the deviation of actual behavior from the normative, whether additional measures are needed.

The logical continuation of the rationale for the importance of reflective processes in management activities on the basis of consideration of its stages and functions can be considered an approach in which the analysis of errors that are most common in management activities. Thus it is possible to reveal the most important key moments of activity connected with the necessity of the reflexive decision of this or that situation. In order for the border guard officer to organize his personal according to their abilities, and be fair in the performance of his daily tasks, it is necessary to constantly assess the staff's behavior. Experts believe that it is impossible to evaluate other people accurately and completely objectively. The manager can only learn to reduce the number of errors that necessarily occur when making estimates. Many experiments ${ }^{7}$ indicate the negative influence of subjective confidence in making an assessment (which, incidentally, is a sign of impulsion in decision-making). Those managers who felt the most confident in making the assessment were often wrong, and the estimates of those managers who felt insecure were significantly more accurate. Uncertain people when observing - more analytical, thoughtful, they consider opposite points of view, analyze different details, attract more information and are ready at any time to doubt their assessment, correct it. Thus, errors in the evaluation of subordinates often arise due to excessive confidence in their rightness, which has developed under

${ }^{7}$ Manhutov, Y. S., Umanskyi, L. Y. (1975). Orhanizator i orhanizatorskaia deiatelnost [Organizer and organizing activity]. Lviv, 310 p. [in Russian]. 
the influence of the initial installation. Besides, in the formation of a correct assessment of the subordinate, the ability to give clear speech formulations to his thoughts plays an important role, since impulsive, inaccurate and vague characteristics cause many misunderstandings when making an assessment.

It should be noted that other errors are also caused by insufficient reflection over the situation, they happen in the process of influencing the subordinate officer. Often, instead of making sense of the situation, the manager uses a stereotypical reaction or stereotypical expressions: "You cannot be charged anything", "You are always late", "This is very similar to you", etc. ${ }^{8}$. The decision can be made too hastily, under the influence of strong emotions. Some situations cause unpleasant associations. In such cases, officers react without understanding, without delving into the details, taking a superficial decision. Lack of selfcontrol, unformed habits of reflection to the situation, could significantly reduce the effectiveness of management. The inability to " broadly " look at the situation, the lack of alternatives in decision-making can make some problems. For example, why does a subordinate work slowly: because he cannot, does not want to work faster, just tired, or is burdened by a state of uncertainty due to instability in the unit? Besides, choosing a way of influence on the subordinate, the border guard officer not always considers the long-term consequences of the behavior. This is especially true of concomitant negative phenomena. The lack of consideration of different points of view, in particular, his own and subordinates can be added.

The next constituent analysis of reflective processes significance in management is a consideration of their role in allocation of professional-important qualities of an officer-borderguard.

It is important to consider that in the structure of a manager the reflection is not simply important, but also acts as an integrator of other properties. Reflexive processes are so actively involved in all managerial functions, that reflection is a part of the vast majority of professionally important qualities.

8 Safin, O. D. (1997). Psykholohiia upravlinskoi diialnosti komandyra: navchalnyi posibnyk [Psychology of commander's management activity: a textbook]. Khmelnytskyi: Vydavnytstvo Akademii PVU, 149 p. [in Ukrainian]. 
In this regard, there are interesting results of experimental researches, indicated by I. Mangutov and L. Uman ${ }^{9}$. We are talking about the specific properties of a skilled organizer. Of the entire number of experiment participants (potential organizers), these properties were found in almost $90 \%$ of cases. The authors describe three qualities.

The first one is "psychological selectivity", which is manifested through several life and experimental indicators:

- Frequent facts of fast, simultaneous, "collapsed", sometimes non-verbal and unconscious reflection of psychological features and states of other people;

- Empathy of the person that feel other people, i.e. emotional synchronicity;

- High sensitivity and susceptibility in the description and demonstration of psychological objects from stories, books, paintings;

- Possibility to characterize psychological peculiarities of people quickly and adequately;

- Preferable choice of psychological objects from many others that simultaneously operate on a person;

- Selective-psychological memory and observation;

- Tendency to psychological analysis, explaining the behavior and actions of other people and their own;

- Deep conviction in the forces and capabilities of the group;

- The ability to mentally visualize themselves in the psychological situation of another person, to think as this person, asking yourself the question: "How would I have done in her/his place?"

Psychological selectivity is the ability to quickly and deeply delve into the psychology of another person, to "understand" it, skillfully changing the tone and form of communication, means and methods of influence. The leader, possessing a psychological selectivity, easily determines what the employee is capable of, catches changes in the team, skillfully groups people. One of the indicators of this property is empathy, ability to stand in the place of another person, empathy.

${ }^{9}$ Morozov, I. V., Zalozh, V. V., Shyrobokov, S. M. (2003). Naukovi osnovy upravlinnia, Chastyna I. [Scientific Foundations of Management, Part I]. Khmelnytskyi.: Vydavnytstvo Natsionalnoi akademii DPSU, 150 p. [in Ukrainian]. 
Interest to people, craving to communicate with them, to remember their deeds are also associated with psychological selectivity. It should be noted that this property, which is especially important for the theoretical generalization of the analyzed literary material, determines the ability to give a characteristic to a person, his psychological portrait, determine the tendency to the psychological analysis, explaining the behavior and deeds of other people and their own.

The second specific characteristic of a skilled organizer, for I. Mangutov and L. Uman, is practically-psychological mind, which is manifested in the following characteristics:

- Distribution of responsibilities of collective activities, taking into account individual characteristics of people;

- Rapid orientation in situations requiring the practical application of human knowledge;

- Quick adaptation of a psychological state, mood of people to certain conditions of activity;

- Ability to induce stimulating motives of activity;

- Taking into account the influence possibilities of personal sympathies and antipathies, psychological differences of people when uniting them to perform collective activities;

- High level of learning in the formation of organizational skills;

- The tendency to solve practical issues through the prism of available human capabilities, a kind of imaginary, "fitting", "weighing" in accordance with the tasks of practice, the number and quality of possible performers.

Practically-psychological mind is the quality that provides the ability to find the best practical application for each person depending on its individual psychological peculiarities. Rapid orientation in situations requiring practical application of people psychology knowledge, ability to solve practical issues taking into account the possibilities of the staff.

The third quality of an organizer is a psychological tact that characterizes the style of communication of the leader with subordinates and colleagues. This is the degree of approach to people in establishing relationships and interactions with them, which is expressed in the ability to find a tone and a form of communication very quickly, depending on the psychological state and the individual characteristics of other people. 
Obviously, this property is also connected with the ability to penetrate into personal inner world, the ability to understand his/her feelings and reactions to the behavior of other people. Three considered properties is a kind of unity. This group specific quality of the authors is called "Organizing flair".

The art of managing largely depends on the ability of a person to feel how it is evaluated by subordinates, and to act as to influence them. Management consciousness of the leader is an internal model of external managerial relationships. The principle of feedback involves the perception of itself only in relations with others, that is, as the other - the reflective "I". The leader self-consciousness related to "I" actual ("What I did and how it influenced the others") and "I" reflective ("How employees and supervisors assess my actions").

If "I" actual expressed the opinion of the leader according to the other, then the "I" reflective - look at myself from the side. If the head is a man, then for him more value may have "I" actual. If the head is a woman, then for her more value may have "I" reflecrive, that is, the assessment of others not only on how it works, but also how it looks. The reflective "I" of the self awareness leader is his "second voice". "I" reflective can correspond to the idea of the head about himself or vice versa, contradict, especially after criticism in his address. This criticism is a threat to the actual "I". If the Supervisor Reboron doubts and recognizes the false manifestation of the actual "I", then this selfregulation of his self awareness is carried out as the restoration of managerial equilibrium with the reflective "I". Managing your behaviour correlates with the estimated expectations of those who may express criticisms. In the minds of the head formed model of possible deviations, which must be avoided in order to maintain the necessary level of self-respect. He/she can lose in his own notion of the past events (focusing on his experience - retrospective reflection) and the present (focusing on possible critical estimates situational reflection) to predict managerial impact effects (perspective reflection). Self-correction of his/her internal relations between the actual "I" and the reflection happens as a self-control of behavior on possible deviations to succeed in managerial activities. 
The organizing abilities of the intuitive plan in literature ${ }^{10}$ include quality as social sensitivity - the ability to understand subordinates, the causes of their actions, the role of each person in the group and the relationship between them. An important skill is also the ability to understand intonations, facial expressions, the human pantomime, the minimum number of external behavioral signs to guess the state of people, with great accuracy to assess the circumstances and factors that preceding this state, and based on intuitive assessment features of any person to predict his/her further behaviour.

The process of awareness, comprehension and reinterpretation of their own activities-so self-reflection is defined by Yu. Krasovskyi ${ }^{11}$. $\mathrm{He}$ also uses the term "reflexive management" - step-by-step understanding of feedbacks, which helps the chief to make managing decisions ahead of time, that is, taking into account the psychological reactions of employees. Speaking about the practical benefits of this process, he emphasizes that it must be valid for the manager. What is important is not self-analysis, but active actions in management in a new way based on your own imagined experiment. You can change yourself, your behavior only when the leader, having reached the "critical point", overcomes it meaningfully, but so that this work of consciousness could lead him to new horizons of his own selfimprovement (creative reflection).

Reflexive management, according to Yu. Krasovskyi, is such an overcoming of "critical points", after which both the head and the employees of his department form a rethought understanding of themselves in the same managerial situations. This is spontaneously fixed in certain phases of professional growth. The author writes about the possibility of managing this process with the help of special training methods, trainings, role-playing and business games focused on reflective processes.

10 Furman, A. V., Humeniuk, O. Y. (2006). Psykholohiia Ya-kontseptsii: Navchalnyi posibnyk [Psychology of self-concept: a textbook]. Lviv: Novyi Svit-2000, 306 p. [in Ukrainian].

${ }^{11}$ Morozov, I. V., Zalozh, V. V., Shyrobokov, S. M. (2003). Naukovi osnovy upravlinnia, Chastyna I. [Scientific Foundations of Management, Part I]. Khmelnytskyi.: Vydavnytstvo Natsionalnoi akademii DPSU, 150 p. [in Ukrainian]. 
Thus, the third aspect of the consideration of the importance of reflexive processes is a reference to the possibility of their initiation and use in the training of managers.

Reflexive management can be especially clearly presented in roleplaying innovative games, which use special techniques and procedures of "cultivation" of new knowledge and cultural patterns of behavior together with the participants of the games (game school of V. Dudchenko, 80-90-ies of XX century).

The aim of the innovative game is to work out the sociopsychological conditions and creative transformation of the personality. Each participant must reconsider himself in the creative self-criticism of the personal "I" in the group solution of innovative problems. This is, according to Yu. Krasovskyi, the highest level of self-reflection, which is formed by group awareness, reflection and rethinking of their professional and personal capabilities.

We can summarize the point of view of Yu. Krasovskyi the following way. Each Manager passes such "critical points" which he somehow realizes, comprehends and rethinks as the implementation of their capabilities in various organizational situations. Thus, it is included in the process of reflexive control of their behavior, which can be modeled using special training techniques.

At reflexive management such reconsideration of administrative activity of the head in which five interconnected processes are combined is supposed.

- The transformation of direct managerial actions into a cooperative-partner feedback system, in which people could work on the basis of long-term interests rather than momentary, which would help to maintain their stability, that is, consistency.

- The performance of such roles by the manager, as well as his employees, would expand and enrich external and internal contacts. As a means of ensuring success in such activities, the author considers participation in specialized role-playing games that help staff to comprehend themselves in new personifications, trying on the "costumes" of different characters (reasoning for another person). It teaches managers to understand the role positions of others, which is very important in the organization of interaction zones. The motto of such games is "Cognize others through yourself and yourself through others...". 
- Reassessment of their responsibilities, opportunities, desires and aspirations in changing situations of partnership, where some win, others lose, and others remain unchanged. There is a more in-depth understanding of themselves, a more correct understanding of business partners, a clearer understanding of how partners perceive themselves, and a clearer understanding of how partners perceive the manager. Interpersonal conflicts, according to Yu. Krasovskyi, arise precisely because employees misunderstand business partners; they do not understand how partners perceive themselves; they do not understand how and why partners perceive themselves in this way.

- Restructuring of management relations of the head in the new organization of joint business partnership on long-term interests and final results with delegation of powers "from the bottom up" and "from the top down". This means the creation of fundamentally new communication networks in which the concept of resource management should prevail. The creation of communication networks in business games helps managers to understand the multidimensional reflective world of assessments and self-assessments and as a result to really rebuild the conditions of future activities.

- Re-orientation of the head from one system of managerial values to another, which fixes a new way of thinking and behavior in his "communicative space" and time perspective. This system of value orientations "leads" the leader "from within" after his reflexive insight: "So it is impossible to work like that anymore!".

To help the officer in the effort to understand what prevents from effective work and how to change the activity, can techniques that work in the mode of reflexive drop. Posing such questions as:" What prevents, and what helps to take the initiative?", "What happens if nothing changes in the management of the unit?" - helps the border guard officer to plunge into a reflexive search, to abandon old stereotypes and find new value orientations.

This is happening especially intense if, in the process of training, officers are involved into specially organized situations with a plot that would inevitably lead them to "critical points" when it is necessary to make responsible decisions based on past experience of joint search for an original idea. At the same time, reflexive control is associated with paradoxes. 
An example of this can be the elements of the scenario of reflexive educational immersion, when the leader can set the task of constructing a new activity, and the head is forced to fix psychological barriers to it, as a result of which he is aware of the change in the conditions of his usual activity. When setting the task to work in a new organizational mode, the transition to a new qualitative state is consolidated and the awareness of their capabilities in the new activity takes place. The task of expanding the area of new organizational interaction helps to identify a different content of activities compared to what was before. The psychological phenomenon accompanies selfdetermination in a new understanding of management situations: "I work for the future", "I no longer waste time in current affairs". This is how the process of self-assessment is constructed, in which the organizational culture of management is transformed into sociopsychological phenomena of changes in the content of professional activity of border guard officers.

Thus, the study of how the activity of a border guard officer changes as a result of reflexive training allows us to draw conclusions about the significant impact of self-assessment on the effectiveness of management activities, which, in turn, requires additional research.

\section{Formation of professional self-assessment of border guard officers}

Modern democratization of society requires new approaches to the personality of the military leader. Complication of tasks assigned to heads of different levels of the State Border Guard Service of Ukraine predetermines their collective decision and understanding of possible consequences $^{12}$.

Self-assessment allows the border guard officer not to focus on himself, his own experiences, and take into account the attitude of other people to himself in order to adjust their own behavior. As practice shows, many border guard officers do not know how to reflect and do not know their level of professional characteristics. This causes

${ }^{12}$ Shreder, H. A. (1994). Rukovodit soobrazno situaci [Manage according to the situation]. M., 1994., 160 p. [in Russian]. 
difficulties in communicating of the border guard officer with his subordinates, conflict situations, etc.

Certain aspects of professional self-assessment have become the subject of research by psychologists E. Bern, A. Derkach, N. Kuzmina, A. Karpova, Ye. Potapchuk, M. Tomchuk, O. Safina, V. Yagupova, T. Yatsenko ${ }^{13,14,15}$. However ways of its acquiring by the border guard officers taking into account special conditions of their activity weren't considered.

Our study first of all considers the issue of professional activity of a border guard officer, which differs from the activity of an officer of the Armed Forces of Ukraine. The main activities in the state border protection units are operational and service activities and daily operations, the results of which are affected by the certain conditions.

At the current stage of development of the State Border Guard Service of Ukraine the issue of effective organization of management of border guard officers is becoming more and more important. Contract service and regular servicemen, a wide range of educational and age range of personnel and consideration of gender differences all complicate the professional activities of a border guard officer. The main difficulties for the officers graduating from the NASBGSU are caused by the organizational and management function related to the collection, analysis and processing of operational and service information, making the appropriate and correct decision, organization of its implementation, selection of adequate forms and methods of professional psychological impact, implementation of effective control. This, in turn, requires the officer to have a developed self-esteem to achieve the best result.

For the description of the model we took into account that its researchers define it as a certain chosen method of "replacement" of the object of study ${ }^{16}$.

13 Orban-Lembryk, L. E. (2003). Psykholohiia upravlinnia [Management Psychology]. Kyiv: Akademvydav, 567 p. [in Ukrainian].

${ }^{14}$ Potapchuk, Y. M. (2003). Viiskova psykholohiia [Military Psychology]. Khmelnytskyi.: Vydavnytstvo NAPVU, 149 p. [in Ukrainian].

15 Iahupov, V. (2004). Viiskova psykholohiia [Military Psychology]: Pidruchnyk. K.: Tandem, 656 p. [in Ukrainian].

${ }^{16}$ Metodiki socialno-psihologicheskoj diagnostiki lichnosti i gruppy [Methods of social and psychological diagnostics of the individual and the group]. (1990). M.: AN SSSR, In-t psikholohii, 219 p. [in Russian]. 
In the structure of the professional reflection model of a border guard officer, we have identified three main components of reflection:

1) Cognitive component of professional reflection, the main indicators of which are the self-analysis of their own professional knowledge, qualities, abilities to manage subdivisions and border guards;

2) Emotional-evaluation component of professional reflection, the main indicators of which are emotional response to the results of professional activity, sense of responsibility, patriotism, satisfaction with the results of professional activity;

3) Behavioural component of professional reflection, the main indicators of which are the understanding of professional actions, behavior, adequacy of own managerial decisions, compliance of actions and behavior with the requirements of the operational environment.

The personality structure of officers with a high level of professional self-esteem differs significantly from that of officers with a low level of professional self-esteem. Taking into account the fact that decision-making processes are a key aspect of management activity, reflexion should be considered as a component of the personality structure of a border guard officer.

The analysis of the practice of border guard officers studying at the National Academy of the State Border Guard Service and state border protection agencies shows that the majority of attention in this process is paid to practical and technical activities, and the main drawbacks in operational and service activities are related to management activities.

In order to determine the state of development of professional self-assessment of border officers, a stating experiment was carried out in the course of which the necessity of forming an influence on the components of professional self-assessment of a border officer was revealed.

It has been established that graduate officers have the lowest level of professional self-esteem. This is due to the fact that young officers are not yet aware of themselves as management officers, and during the first year they are adapted to the special conditions of the border guards. Among other officers, a high number of those who work directly with unit personnel, often operate in volatile operational 
environments and make responsible decisions. Rather high figures were shown by the officers, students of the operational-tactical faculty of NASBGSU, which can be explained by the fact that they had passed a special professional selection before joining.

The program for the formation of professional self-esteem was created. The content of it is outlined in Fig. 1.

\begin{tabular}{|c|c|c|c|}
\hline № & Name of the event & $\begin{array}{l}\text { Amount } \\
\text { of hours }\end{array}$ & $\begin{array}{c}\text { Formation } \\
\text { of reflection } \\
\text { components }\end{array}$ \\
\hline \multirow{5}{*}{1} & Course of lectures: & & \\
\hline & $\begin{array}{l}\text { Lecture 1: The essence of the professional } \\
\text { self-assessment of a border guard officer }\end{array}$ & 1 & Cognitive \\
\hline & $\begin{array}{l}\text { Lecture 2: The Impact of Professional } \\
\text { Self-Esteem on the Management Activity } \\
\text { of an Officer }\end{array}$ & 1 & Cognitive \\
\hline & $\begin{array}{l}\text { Lecture 3: Objective indicators and self- } \\
\text { assessment of professional activity of } \\
\text { border guards }\end{array}$ & 1 & Cognitive \\
\hline & $\begin{array}{l}\text { Lecture 4: Ways to Form a Professional } \\
\text { Self-Assessment of a Border Guard } \\
\text { Officer }\end{array}$ & 1 & Cognitive \\
\hline 2 & $\begin{array}{l}\text { Round table discussion, analysis and } \\
\text { reflection of problem situations, comp- } \\
\text { lex tasks in managing the operational and } \\
\text { operational activities of the unit }\end{array}$ & 2 & $\begin{array}{l}\text { Cognitive } \\
\text { Emotionally } \\
\text { valuable }\end{array}$ \\
\hline 3 & $\begin{array}{l}\text { Group session on introspection of levels } \\
\text { of individual professional reflection }\end{array}$ & 2 & $\begin{array}{l}\text { Cognitive } \\
\text { Emotionally } \\
\text { valuable } \\
\text { Behavioral } \\
\end{array}$ \\
\hline 4 & $\begin{array}{l}\text { Business game for solving situational } \\
\text { problems of management activity in } \\
\text { changes of operational situation on the } \\
\text { state border }\end{array}$ & 2 & $\begin{array}{l}\text { Cognitive } \\
\text { Emotionally } \\
\text { valuable } \\
\text { Behavioral } \\
\end{array}$ \\
\hline \multirow[t]{2}{*}{5} & $\begin{array}{l}\text { Training on formation of professional } \\
\text { self-assessment of a border guard officer }\end{array}$ & 54 & $\begin{array}{l}\text { Cognitive } \\
\text { Emotionally } \\
\text { valuable } \\
\text { Behavioral } \\
\end{array}$ \\
\hline & & $\begin{array}{l}\text { In total: } \\
64 \text { hours }\end{array}$ & \\
\hline
\end{tabular}

Fig. 1. The Program for the Formation of Professional Self-esteem of Border Guards 
The model of formation of professional self-esteem is shown in fig. 2 .

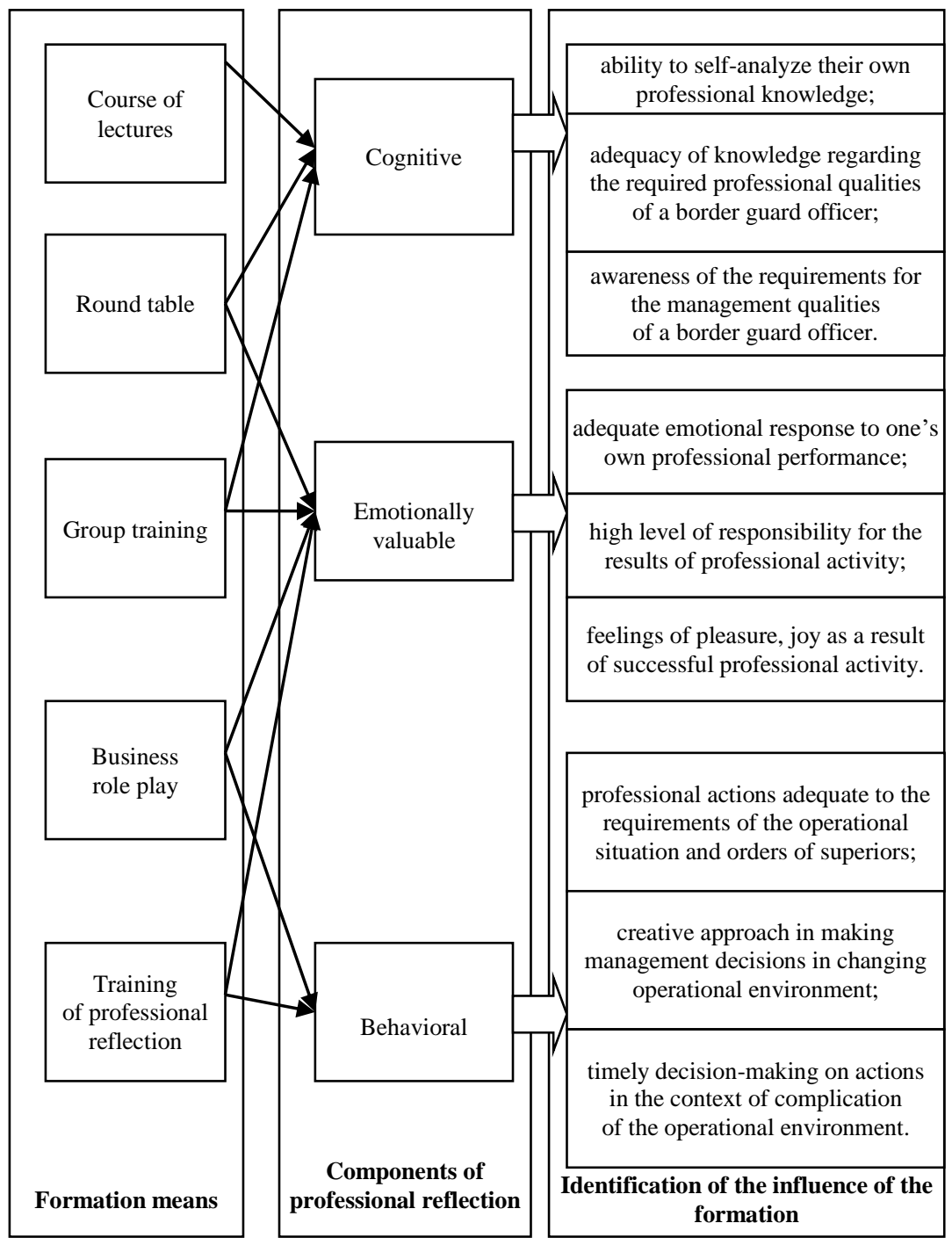

Fig. 2. The Model of Professional Self-assessment Formation of the Border Guard Officer 


\section{CONCLUSIONS}

1. There is a clear relationship between the level of self-esteem and the management characteristics of the border guard officer.

2. Socio-psychological characteristics of management activity in parts and subdivisions of the State Border Guard Service of Ukraine, the need to take into account democratic values in connection with its reform and approximation to European standards lead to an increase in the demand for the personal qualities of border guards officers, their ability to take into account the opinions of other experts and people in their professional activity.

3. Since decision-making processes are a key element of managerial activity, self-esteem must be considered as a part of the personality of the border guard officer.

4. The personality structure of officers who have a high level of professional self-esteem development is significantly different from the personality structure of officers who have a low level of professional self-esteem development.

5. Thus, the components of the model of formation of the professional self-assessment of the border guard are: means of influencing the components of the professional reflection of the border guard (set forth in the program of formation of the professional selfassessment of the border guard), the components of the professional self-assessment of the border guard, which are affected performance indicators that allow predicting the impact of the impact on the professional self-esteem of the border guard officer (Fig. 2).

The development of this model can effectively organize the work on the development of the professional self-assessment of the border guard officer and significantly increase the efficiency of his professional activity. In the following, we used the model and the experimental data to develop recommendations to the heads of different structures of the SBGS regarding the development of the professional self-assessment of a border guard officer.

\section{SUMMARY}

The article is devoted to analysis of the scientific papers presenting results of research on the concept of "self-esteem of a border guard officer" in the system of his professional activity and creation of a program and model of its formation. The components of 
the model of professional self-assessment formation of the border guard officers include means of influencing the components of the professional reflection of the border guard officers (outlined in the program of forming the professional self-assessment of the border guard officers), the components of professional self-assessment of the border guard officers, and the performance indicators. They make it possible to predict the impact on the border guard officer's professional self-assessment formation. The development of this model can effectively organize the work on the formation of the professional self-assessment of the border guard officer and significantly increase the efficiency of his professional activity. In the future, we used the above mentioned model and the experimental data to develop recommendations for the heads of different structures of the SBGS regarding the development of the professional self-assessment of a border guard officer.

\section{REFERENCES}

1. Morozov, I. V., Zalozh, V. V., Shyrobokov, S. M. (2003). Naukovi osnovy upravlinnia, Chastyna I. [Scientific Foundations of Management, Part I]. Khmelnytskyi.: Vydavnytstvo Natsionalnoi akademii DPSU, 150 p. [in Ukrainian].

2. Smolskij, S. M., Filippov, L. I. (2005). Tri shaga k professii: nauka, disertaciya, pedagogika [Three steps to the profession: science, dissertation, pedagogy]. Odessa: "Neptun-Tehnologiya", 125 p. [in Russian].

3. Potapchuk, Y. M. (2004). Teoriia ta praktyka zberezhennia psykhichnoho zdorovia viiskovosluzhbovtsiv: Monohrafiia [Theory and practice of maintaining the mental health of servicemen: A monograph]. Khmelnytskyi: Vydavnytstvo Natsionalnoi akademii DPSU, 323 p. [in Ukrainian].

4. Safin, O. D. (1997). Psykholohiia upravlinskoi diialnosti komandyra: navchalnyi posibnyk [Psychology of commander's management activity: a textbook]. Khmelnytskyi: Vydavnytstvo Akademii PVU, 149 p. [in Ukrainian].

5. Furman, A. V., Humeniuk, O. Y. (2006). Psykholohiia Ya-kontseptsii: Navchalnyi posibnyk [Psychology of self-concept: a textbook]. Lviv: Novyi Svit-2000, 306 p. [in Ukrainian]. 
6. Manhutov, Y. S., Umanskyi, L. Y. (1975). Orhanizator i orhanizatorskaia deiatelnost [Organizer and organizing activity]. Lviv, 310 p. [in Russian].

7. Metodiki socialno-psihologicheskoj diagnostiki lichnosti i gruppy [Methods of social and psychological diagnostics of the individual and the group]. (1990). M.: AN SSSR, In-t psikholohii, 219 p. [in Russian].

8. Orban-Lembryk, L. E. (2003). Psykholohiia upravlinnia [Management Psychology]. Kyiv: Akademvydav, 567 p. [in Ukrainian].

9. Potapchuk, Y. M. (2003). Viiskova psykholohiia [Military Psychology]. Khmelnytskyi.: Vydavnytstvo NAPVU, 149 p. [in Ukrainian].

10. Iahupov, V. (2004). Viiskova psykholohiia [Military Psychology]: Pidruchnyk. K.: Tandem, 656 p. [in Ukrainian].

11. Shreder, H. A. (1994). Rukovodit soobrazno situaci [Manage according to the situation]. M., 1994., 160 p. [in Russian].

\section{Information about the author: Valentyn Demskyi}

Head of Psyhology and Moral and Psyhological Support Department National Academy of the State Border Guard Service of Ukraine named after Bohdan Khmelnytskyi 46, Shevchenko str., Khmelnytskyi, 29003, Ukraine ORCID ID: orcid.org/0000-0003-4777-9392 